\title{
Sexual Dysfunction Related to Drugs: A Critical Review. Part IV: Cardiovascular Drugs
}

Authors

Affiliations

\author{
A. La Torre ${ }^{2}$, G. Giupponi ${ }^{1}$, D. Duffy ${ }^{1}$, A. Conca ${ }^{1}$, D. Catanzariti ${ }^{3}$
}

${ }^{1}$ Department of Psychiatry, S. Maurizio Hospital, Bolzano Italy ${ }^{2}$ Department of Psychiatry, Ospedale di Rovereto, Rovereto, Italy ${ }^{3}$ U. O. di Cardiologia, Ospedale di Rovereto, Rovereto, Italy
Key words

- cardiovascular drugs

- sexual dysfunction

- sexual side effects

treatment-emergent sexual dysfunction received $\quad$ 18.09.2014

revised $\quad 18.09 .2014$

accepted $\quad 06.10 .2014$

\section{Bibliography}

DOI http://dx.doi.org/

10.1055/s-0034-1395515

Published online:

November 18, 2014

Pharmacopsychiatry 2015;

48: 1-6

(c) Georg Thieme Verlag KG Stuttgart · New York

ISSN 0176-3679

Correspondence

\section{G. Giupponi}

Psychiatrie

S. Maurizio Hospital

Via Boehler nr. 4

I-39100 Bolzano

Italy

giancarlo.giupponi@asbz.it

\section{Abstract}

$\nabla$

Introduction: Sexual dysfunction is a potential side effect of cardiovascular drugs: this article is a critical review of the current literature. Many studies have been published on this topic. Most of these studies are not methodologically robust, few are RCTs and most did not use a validated rating scale to evaluate sexual functioning. In addition, other methodological flaws limit greatly the conclusions of these studies. Most studies relate to male populations and only a few have been conducted on women. Also, the majority of studies on sexual dysfunction induced by cardiovascular drugs relate to antihypertensive drugs. While there is evidence to suggest that older antihypertensive drugs (diuretics, beta-blockers, centrally acting agents) have a negative impact on erectile function, newer agents seem to have either neutral (ACE inhibitors, calcium antagonists) or beneficial effects (i.e., angiotensin receptor blockers, nebivolol). Other cardiovascular drugs analyzed in this review also appear to have an inhibitory action on sexual function. For men, there is some weak evidence supporting the use of specific treatment strategies for sexual dysfunction associated with these drugs.

\section{Introduction: Sexual Dysfunction Induced by Cardiovascular Drugs $\nabla$}

Excluding psychotropic and antiepileptic drugs (for which there are previous published reviews [1-3]), there are many other drugs that may be responsible for sexual dysfunction.

In view of the heterogeneity of these drugs, it was considered useful to list them according to the ATC system used by the World Health Organization. ATC is an acronym for "Anatomical Therapeutic Chemical Classification System", which can be viewed in detail on the web-site of the WHO [4].
Methods: This study was conducted in 2014 using the paper and electronic resources of the library of the "Azienda Provinciale per i Servizi Sanitari (APSS)" in Trento, Italy (http://atoz. ebsco.com/Titles/2793). The library has access to a wide range of databases including DYNAMED, MEDLINE Full Text, CINAHL Plus Full Text, The Cochrane Library, Micromedex healthcare series, BMJ Clinical Evidence. The full list of available journals can be viewed at http://atoz.ebsco.com/ Titles/2793 or at the APSS web site (http://www. apss.tn.it). In completing this review, a literature search was conducted using the key words "cardiovascular", "adrenergic beta antagonist", “ $\alpha 1$-adrenoceptor antagonist”, “angiotensin converting enzyme inhibitor", “angiotensin receptor antagonist”, “angiotensin receptor blocker", "beta blocker", "beta receptor antagonist", "calcium channel blocker”, “diuretic”, "antihypertensive", "sexual dysfunction", "sexual side effects", "treatment-emergent sexual dysfunction". All resulting listed articles were reviewed.

Conclusion: The review includes studies that investigated the relationship between these drug treatments and sexual dysfunction. The purpose was to identify possible intervention strategies for sexual dysfunction related to these drugs.

In the following Tables we have indicated only the "drug class": all drugs listed in the Tables fall within the "Anatomical Main Group" (which corresponds to the first level of the ATC classification system) called "Cardiovascular System".

Most of the studies conducted on the potential side effects of cardiovascular drugs on sexual dysfunction concern antihypertensive drugs. Most of these studies have been conducted on. Erectile dysfunction is the most frequently investigated sexual dysfunction: other sexual dysfunctions are rarely investigated (especially for women). 
Although male sexual function has been studied rather extensively, female sexual dysfunction in hypertension is underexplored [5-8]: female sexual dysfunction remains substantially understudied compared to erectile dysfunction $[7,9]$. The main limitation of existing studies is the failure to use a standard definition for sexual dysfunction: the classification of sexual dysfunction proposed by ICD-10 or DSM-IV-TR or DSM5 (which receives the greatest international consensus) is very rarely used [10-12].

Survey methods are often inadequate: rating scales are rarely used for the detection of specific sexual dysfunctions, with the exception only of the IIEF (International Index of Erectile Function) [13] and the FSFI (Female Sexual Function Index) [14]. According to Rosen [15], however, the IIEF has many limitations: it provides little information on other domains of sexual functioning, other than erection. A second limitation of the IIEF is that it does not evaluate ejaculatory function (i.e., the volume and force of ejaculate, delayed or premature ejaculation, pain/ discomfort and pleasure during ejaculation). A third limitation of the IIEF is that it does not provide information about the patient's sexual relationship or the sexual functioning of their partner. A fourth limitation of the IIEF is that it focuses exclusively on vaginal sexual intercourse, and is therefore not appropriate for use in non-heterosexual men [15]. Duncan et al. [16] have proposed the use of another questionnaire to evaluate female sexual functioning, hypertension and medication effects in premenopausal women.

Although questionnaires may not provide objective information on sexual dysfunction, the response rate to direct questioning may be less than the response rate to a questionnaire and may also be affected by the gender or ethnicity of the interviewer [17]. The failure to use specific rating scales means that the conclusions of these studies are limited and inconclusive and that further confirmatory studies are needed.

Although early reports of sexual dysfunction induced by antihypertensive drugs date as far back as 30 and even 40 years ago [18-21], few RCTs (randomized clinical trials) have been conducted.

Due to the methodological limitations of previous studies it is possible to conclude only that the sexual effects of cardiovascular drugs may be either "positive", "negative" or "neutral"; findings that are difficult to interpret have been reported as "uncertain results". In view of the extreme heterogeneity of study methods used in the investigation of drug-induced sexual dysfunction, it is impossible to summarize in detail the findings of these studies, which should be consulted for further information.

The findings of existing studies are contradictory. Older antihypertensive drugs (diuretics, beta-blockers, centrally acting agents) have been shown to have a negative impact on erectile function, while newer agents have been shown to have either neutral (ACE inhibitors, calcium antagonists) or beneficial effects (angiotensin receptor blockers, nebivolol) [22-35]: contrasting findings have been described by Erdmann [36] who states that erectile dysfunction is no more common with beta-blockers than with any other drug prescribed for chronic heart failure or hypertension. Similar conclusions are also reached by Ko et al. [37]. Ferrario et al. [38] report that deleterious effects of diuretics and beta-blockers on sexual function have not been consistently found, and that several controlled studies (including TOMHS and a combined analysis of 6 blind randomized prospective trials) have found little or no evidence that sexual side effects are more common with these agents compared to other antihypertensive medications. The study by Blumentals et al. [39] appears to support the hypothesis that diuretics do not cause erectile dysfunction. Unlike other studies, Shiri et al. [40] found a higher incidence of erectile dysfunction in men using angiotensin II inhibitors compared with non-users.

Several mechanisms of action are involved in the effect of antihypertensive drugs on sexual function [41]. Oxidative stress plays a crucial role in the mechanism of erectile dysfunction, and includes endothelial dysfunction induced by decreased nitric oxide (NO) bioavailability and ROS (reactive oxygen species) overproduction [8]. Angiotensin II is synthesized in the corpus cavernosum, it is involved in detumescence of the corpus cavernosum and produces oxidative stress in the penile endothelium which in turn may lead to the development of erectile dysfunction. It is reasonable to assume that oxidative stress might also be involved in the mechanism of anti-hypertensive druginduced sexual dysfunction in women [8]. The favorable effects of ARB (angiotensin receptor blockers) on sexual function may be related, in part, to their ability to block angiotensin II, which has recently become recognized as an important mediator of detumescence and possibly of erectile dysfunction [38]. Beta blockers (e.g., atenolol and propranolol) may potentially impact on sexual functioning through a variety of mechanisms, including a reduction in central sympathetic outflow, impairment of vasodilation of the corpora cavernosa, effects on luteinizing hormone and testosterone secretion and a tendency to produce sedation or depression, thereby causing a loss of libido [38]. Alpha blockers are believed to have the potential to interfere with corporal smooth muscle constriction [39]. Digoxin may cause erectile dysfunction by acting on corpus cavernosum smooth muscle contractility and or by influencing libido or serum testosterone, estrogen or luteinizing hormone levels $[19,42]$. However, other studies have shown no action of digoxin on plasma steroid levels $[43,44]$. There have been reports of gynecomastia caused by increased levels of prolactin during treatment with calcium channel blockers and with spironolactone $[45,46]$. Psychological factors ("nocebo effect") have also been implicated as being responsible for sexual dysfunction in patients treated with antihypertensive drugs $[47,48]$.

It therefore remains unclear whether the effects on sexual function are due to the antihypertensive drugs or due to the hypertension itself, or to both $[24,25,49]$.

\section{Discussion and Conclusion}

$\nabla$

In keeping with Düsing [25], we found that the number of reviews and commentary articles on the effects of antihypertensive treatment on sexual function far exceeds the number of original study reports.

\begin{tabular}{|c|c|}
\hline negative effect & $(-)$ \\
\hline no significant effect & $(+/-)$ \\
\hline positive effect & $(+)$ \\
\hline uncertain results & (?) \\
\hline
\end{tabular}


In addition, there is remarkably few data on sexual dysfunction and the widely prescribed combination antihypertensive treatments. In short, only a large well designed, randomized, doubleblind, prospective trial can clarify questions about the specific effects of various antihypertensive drug classes on sexual function $[50,51]$.
Although the British Society for Sexual Medicine highly recommends the routine assessment of sexual function prior to initiation of an antihypertensive treatment, this recommendation remains largely ignored by clinicians $[52,53]$. In fact, only a minority of CPGs (clinical practice guidelines) for the treatment of hypertension actually consider erectile dysfunction or other

Table 2 Effects of cardiovascular drugs on sexual function.

\begin{tabular}{|c|c|c|c|c|}
\hline Drug class & Drug & $\begin{array}{l}\text { Effect on sexual function } \\
\text { in men }\end{array}$ & $\begin{array}{l}\text { Effect on sexual } \\
\text { function in women }\end{array}$ & $\begin{array}{l}\text { Effect on sexual function in } \\
\text { men and women }\end{array}$ \\
\hline \multirow{4}{*}{$\begin{array}{l}\text { Antihypertensives, anti-adrenergic agents, } \\
\text { centrally acting }\end{array}$} & & $(-)[25,63]$ & & \\
\hline & methyldopa & $(+/-)[18],(-)[64-66],(?)[67]$ & (?) [68] & \\
\hline & clonidine & $(+/-)[69],(-)[66],(?)[67]$ & (?) [68], (+/-) [69] & \\
\hline & reserpine & (?) [67] & (?) [68] & \\
\hline \multicolumn{5}{|l|}{$\begin{array}{l}\text { Antihypertensives, antiadrenergic agents, } \\
\text { peripherally acting, guanidine derivatives }\end{array}$} \\
\hline & betanidine & $(-)[18]$ & & \\
\hline & guanethidine & $(-)[18,67]$ & (?) [68] & \\
\hline \multirow{3}{*}{$\begin{array}{l}\text { Antihypertensives, antiadrenergic agents, } \\
\text { peripherally acting, alpha-adrenoreceptor } \\
\text { antagonists }\end{array}$} & & $(-)[39]$ & & \\
\hline & doxazosin & $(+/-)[70]$ & & \\
\hline & prazosin & & $(+/-)[69]$ & \\
\hline \multirow[t]{6}{*}{ Beta blocking agents, selective } & & & $(-)[6]$ & $(+/-)[36]$ \\
\hline & metoprolol & $(-)[71],(+/-)[72]$ & $(-)[8]$ & $(+/-)[73]$ \\
\hline & atenolol & $(-)[74-77],(+/-)[48,78]$ & $(-)$ [79] & \\
\hline & acebutolol & $(+/-)[70]$ & & \\
\hline & nebivolol & $(+)[71,74,80-83]$ & & \\
\hline & bisoprolol & & & $(+/-)[84]$ \\
\hline \multirow[t]{2}{*}{ Beta blocking agents, non-selective } & & $(-)[25,63]$ & & $(+/-)[37]$ \\
\hline & propranolol & $(-)[64-67]$ & & $(+/-)[73]$ \\
\hline
\end{tabular}

Table 3 Effects of cardiovascular drugs on sexual function.

\begin{tabular}{|c|c|c|c|c|}
\hline Drug class & Drug & $\begin{array}{l}\text { Effect on sexual } \\
\text { function in men }\end{array}$ & $\begin{array}{l}\text { Effect on sexual } \\
\text { function in women }\end{array}$ & $\begin{array}{l}\text { Effect on sexual function } \\
\text { in men and women }\end{array}$ \\
\hline \multicolumn{5}{|l|}{$\begin{array}{l}\text { Beta blocking agents, alpha- } 1 \text { and beta blocking } \\
\text { agents }\end{array}$} \\
\hline & labetalol & & (?) [68], (-) [85] & \\
\hline & carvedilol & $(-)[81,86]$ & & \\
\hline \multicolumn{5}{|l|}{$\begin{array}{l}\text { Antihypertensives, arteriolar smooth muscle, agents } \\
\text { acting on hydrazinophthalazine derivatives }\end{array}$} \\
\hline & hydralazine & $(-)[66]$ & & \\
\hline \multirow[t]{4}{*}{ Diuretics, low-ceiling diuretics, thiazides } & & $(-)[25,63,87]$ & (?) [68] & \\
\hline & bendroflumethiazide & $(-)[63]$ & & \\
\hline & hydrochlorothiazide & $(-)[66,88-89]$ & & $(+/-)[84]$ \\
\hline & trichlormethiazide & $(-)[77]$ & & $(-)[90]$ \\
\hline \multicolumn{5}{|l|}{$\begin{array}{l}\text { Diuretics, high-ceiling diuretics, excluding thiazides, } \\
\text { sulfonamides. }\end{array}$} \\
\hline & furosemide & $(+/-)[88]$ & & \\
\hline \multirow{2}{*}{$\begin{array}{l}\text { diuretics, low-ceiling diuretics, excluding thiazides, } \\
\text { sulfonamides }\end{array}$} & & $(-)[25,63]$ & & \\
\hline & chlortalidone & $(-)[70,74,78,91]$ & & \\
\hline \multirow[t]{3}{*}{ Potassium-sparing agents, aldosterone antagonists } & & $(-)[25,63]$ & & $(-)[92]$ \\
\hline & spironolactone & $(-)[46,93]$ & & $(-)[92,94]$ \\
\hline & eplerenone & & & $(-)[95]$ \\
\hline \multirow{2}{*}{$\begin{array}{l}\text { Potassium-sparing agents, other potassium-sparing } \\
\text { agents }\end{array}$} & & & & $(-)[92]$ \\
\hline & amiloride & & & $(-)[92]$ \\
\hline \multirow[t]{2}{*}{ Cardiac glycosides, Digitalis glycosides } & & $(+/-)[43,44,96]$ & & \\
\hline & digoxin & $(-)[19,42,97,98]$ & & \\
\hline \multicolumn{5}{|l|}{ Antiarrhythmics, class la } \\
\hline & disopyramide & $(-)[99]$ & & \\
\hline
\end{tabular}


Table 4 Effects of cardiovascular drugs on sexual function.

\begin{tabular}{|c|c|c|c|c|}
\hline Drug class & Drug & $\begin{array}{l}\text { Effect on sexual } \\
\text { function in men }\end{array}$ & $\begin{array}{l}\text { Effect on sexual } \\
\text { function in women }\end{array}$ & $\begin{array}{l}\text { Effect on sexual function } \\
\text { in men and women }\end{array}$ \\
\hline \multicolumn{5}{|l|}{ Antiarrhythmics, class Ic } \\
\hline & propafenon & $(-)[100]$ & & \\
\hline \multirow[t]{5}{*}{$\begin{array}{l}\text { Agents acting on the renin-angiotensin system, ACE } \\
\text { (angiotensin-converting enzyme) inhibitors }\end{array}$} & & $\begin{array}{l}(+)[22,57,76], \\
(-)[39]\end{array}$ & & \\
\hline & captopril & $(+/-)[65,77]$ & & \\
\hline & enalapril & & & $(+/-)[70,84,101]$ \\
\hline & lisinopril & $(+/-)[76,88]$ & & \\
\hline & ramipril & $(+/-)[102]$ & & \\
\hline \multirow{5}{*}{$\begin{array}{l}\text { Agents acting on the renin-angiotensin system, } \\
\text { angiotensin II antagonists (ARB: angiotensin receptor } \\
\text { blockers) }\end{array}$} & & $\begin{array}{l}(+)[22,29,38] \\
(-)[40]\end{array}$ & & $(+)[53]$ \\
\hline & losartan & $(+)[103]$ & & \\
\hline & valsartan & $\begin{array}{l}(+)[27,83,86,104,105] \\
(+/-)[75]\end{array}$ & $(+)[79]$ & \\
\hline & irbesartan & $(+)[106-108]$ & $(+)[8]$ & \\
\hline & telmisartan & $(+/-)[102]$ & & \\
\hline \multirow{2}{*}{$\begin{array}{l}\text { Selective calcium channel blockers with mainly vascular } \\
\text { effects, phenylalkylamine derivatives }\end{array}$} & & $(+)[22]$ & & \\
\hline & verapamil & $(-)[109],(+/-)[88]$ & & \\
\hline \multicolumn{5}{|l|}{$\begin{array}{l}\text { Selective calcium channel blockers with mainly vascular } \\
\text { effects, benzothiazepine derivatives }\end{array}$} \\
\hline & diltiazem & (?) [88] & & \\
\hline \multicolumn{5}{|l|}{$\begin{array}{l}\text { Selective calcium channel blockers with mainly vascular } \\
\text { effects, dihydropyridine derivatives }\end{array}$} \\
\hline & amlodipine & $(+/-)[70]$ & & $(+/-)[84,101]$ \\
\hline & nicardipine & & & $(+/-)[90]$ \\
\hline & nifedipine & $(-)[77],(?)[88]$ & & \\
\hline & felodipine & $(+/-)[108]$ & $(+)[8]$ & \\
\hline Vasodilators used in cardiac disease, organic nitrates & & $(+/-)[40]$ & & \\
\hline
\end{tabular}

sexual issues as potential adverse outcomes or as factors to consider in treatment [54]. It has been shown that sexual function is not routinely discussed with patients in cardiology practices [55]. A recent study has shown that cardiologists' knowledge about the effects of cardiovascular drugs on sexual function appears to be insufficient [56]. Increased awareness among cardiologists on sexual function, and adequate assessment and appropriate counselling of any identified sexual impairment is needed [57].

Sexual function should be assessed in all hypertensive patients, both at diagnosis and after the introduction of new drugs. The first step in its management is to identify and effectively treat any comorbid conditions. Secondly, it is prudent to adjust the antihypertensive treatment with consideration of the comorbid illness and also after taking into account the risk of sexual dysfunction for each choice of drug [58].

In men, symptomatic treatment with inhibitors of phosphodiesterase- 5 has been evaluated $[59,60]$.

The use of alpha-blockers may lead to a significant interaction with PDE-5 inhibitors, however the use of organic nitrates, either short-acting, or long-acting in patients with ischemic heart disease, is a contraindication for the use of PDE-5 inhibitors [61,62]. Sublingual apomorphine has also been proposed in the management of erectile dysfunction induced by antihyperthensive drugs [58].

The following $\bullet$ Table 1-4 summarize the effect of cardiovascular drugs on sexuality.

Randomized clinical trials conducted primarily on female users are needed.
In general, further studies using specific diagnostic criteria and rating scales in order to detect and to specify the type and the extent of sexual dysfunction induced by cardiovascular drugs are needed.

The widely reported findings in the literature that some cardiovascular drugs have either neutral or beneficial effects on erectile function should be confirmed by further studies using more precise methods of investigation, in particular studies that use specific diagnostic criteria and rating scales.

\section{Conflict of Interest \\ $\nabla$}

Prof. Dr. Andreas Conca has served as consultant for Lilly (Italy) and on speakers bureau of Janssen, Lilly, Otsuka, Lundbeck. Dr. Giupponi has served as a speaker for Lilly (Italy).

\section{References}

1 La Torre A, Giupponi G, Duffy DMU et al. Sexual dysfunction related to psychotropic drugs: a critical review. Part I: antidepressants. Pharmacopsychiatry 2013; 46: 191-199

2 La Torre A, Conca A, Duffy DMU et al. Sexual dysfunction related to psychotropic drugs: a critical review. Part II: antipsychotics. Pharmacopsychiatry 2013; 46: 201-208

3 La Torre A, Giupponi G, Duffy DMU et al. Sexual dysfunction related to psychotropic drugs: a critical review. Part III: mood stabilizer and anxiolytic drugs. Pharmacopsychiatry $2014 ; 47: 1-6$

4 WHO Collaborating Centre for Drug Statistics Methodology. ATC. Structure and principles.Available on line at: http://www.whocc.no/atc/ structure_and_principles/(accessed on 10 May 2014)

5 Doumas $M$, Doumas $S$. Sexual dysfunction in essential hypertension: myth or reality? J Clin Hypertens 2006; 8, 4: 269-274 
6 Doumas $M$, Tsiodras $S$, Tsakiris A et al. Female sexual dysfunction in essential hypertension: a common problem being uncovered. J Hypertens 2006; 24: 2387-2392

7 Doumas M, Anyfanti P, Lazaridis N. Effects of antihypertensive therapy on female sexual dysfunction: clinically meaningful? J Hypertens 2012; 30: 1263-1264

$8 \mathrm{Ma} \mathrm{R}, \mathrm{Yu} \mathrm{J}, \mathrm{Xu} \mathrm{D}$ et al. Effect of felodipine with irbesartan or metoprolol on sexual function and oxidative stress in women with essential hypertension. J Hypertens 2012; 30: 210-216

9 Douma S, Doumas M, Tsakiris A et al. Male and female sexual dysfunction: is hypertension an innocent bystander or a major contributor? Rev Bras Hipertens 2007; 14: 139-147

10 WHO. International Classification of Diseases (ICD) and Related Health Problems. $10^{\text {th }}$ Revision (ICD-10). Available on line at: http://apps. who.int/classifications/icd10/browse/2010/en\#/V (accessed on 10 May 2014)

11 American Psychiatric Association. Diagnostic and Statistical Manual of Mental Disorders, Fourth Edition, Text Revision (DSM-IV-TR). American Psychiatric Publ, 2010

12 American Psychiatric Association. Diagnostic and Statistical Manual of Mental Disorders, Fifth Edition (DSM-5). Arlington, VA: 2013

13 Rosen $R$, Riley A, Wagner $G$ et al. The International Index of Erectile Function (IIEF): A multidimensional scale for assessment of erectile dysfunction. Urology 1997; 49: 822-830

14 Rosen R, Brown C, Heiman J et al. The Female Sexual Function Index (FSFI): A multidimensional self-report instrument for the assessment of female sexual function. J Sex Mar Ther 2000; 26: 191-208

15 Rosen $R C$. Assessment of sexual dysfunction in patients with benign prostatic hyperplasia. BJU Int 2006; 97 (Suppl 2): 29-33

16 Duncan LE, Lewis C, Smith CE et al. Sex, drugs, and hypertension: a methodological approach for studying a sensitive subject. Int J Impot Res 2001; 13: 31-40

17 Prisant LM, Carr AA, Bottini PB et al. Sexual dysfunction with antihypertensive drugs. Arch Intern Med 1994; 154: 730-736

18 Bulpitt CJ, Dollery CT. Side effects of hypotensive agents evaluated by a self-administered questionnaire. Br Med J 1973; 3: 485-490

19 Stoffer SS, Hynes KM, Jiang N-S et al. Digoxin and abnormal serum hormone levels. JAMA 1973; 225: 1643-1644

20 Bauer GE, Baker J, Hunyor SN et al. Side-effects of antihypertensive treatment: a placebo-controlled study. Clin Sci Mol Med 1978; (Suppl 4): 341s-344s

21 Stevenson JG, Umstead GS. Sexual dysfunction due to antihypertensive agents. Drug Intell Clin Pharm 1984; 18: 113-121

22 Baumhäkel M, Schlimmer N, Kratz $M$ et al. Cardiovascular risk, drugs and erectile function - a systematic analysis. Int J Clin Pract 2011; 65: 289-298

23 Doumas $M$, Douma $S$. The effect of antihypertensive drugs on erectile function: a proposed management algorithm. J Clin Hypertens 2006; 8: 359-364

24 Doumas $M$, Viigimaa $M$, Papademetriou V. Combined antihypertensive therapy and sexual dysfunction: terra incognita. Cardiology 2013; 125: 232-234

25 Düsing $R$. Sexual dysfunction in male patients with hypertension. Drugs 2005; 65: 773-786

26 Finger WW, Slagle MA. Male sexual dysfunction: pathophysiology and treatment. Informa Medical. 2009 edited by Kandeel FR.

27 Fogari R, Zoppi A. Effects of antihypertensive therapy on sexual activity in hypertensive men. Curr Hypertens Rep 2002; 4: 202-210

28 Fogari R, Zoppi A. Effects of antihypertensive agents on quality of life in the elderly. Drugs Aging 2004; 21: 377-393

29 Garko B, Ogunsina MO, Danbauchi SS. Sexual dysfunction in hypertensive patients: implications for therapy. Ann Afr Med 2005; 4: 46-51

30 Giuliano F, Droupy S. La iatrogénie médicamenteuse en médecine sexuelle. Prog Urol 2013; 23: 804-810

31 Krause W. Drugs Compromising Male Sexual Health. Springer-Verlag, Berlin Heidelberg: 2008

32 Manolis A, Doumas $M$. Antihypertensive treatment and sexual dysfunction. Curr Hypertens Rep 2012; 14: 285-292

33 Manolis A, Doumas M. Sexual dysfunction: the 'prima ballerina' of hypertension-related quality-of-life complications. J Hypertens 2008; 26: 2074-2084

34 Nicolai MPJ, Liem SS, Both S et al. A review of the positive and negative effects of cardiovascular drugs on sexual function: a proposed table for use in clinical practice. Neth Heart J 2014; 22: 11

35 Shindel AW, Kishore S, Lue TF. Drugs designed to improve endothelial function: effects on erectile dysfunction. Curr Pharm Des 2008; 14 : 3758-3767
36 Erdmann E. Safety and tolerability of beta-blockers: prejudices and reality. Eur Heart J Suppl 2009; 11: A21-A25

37 Ko DT, Hebert PR, Coffey CS et al. Beta-blocker therapy and symptoms of depression, fatigue, and sexual dysfunction. JAMA 2002; 288 : 351-357

38 Ferrario CM, Levy P. Sexual dysfunction in patients with hypertension: implications for therapy. J Clin Hypertens 2002; 4: 424-432

39 Blumentals WA, Brown RR, Gomez-Caminero A. Antihypertensive treatment and erectile dysfunction in a cohort of type II diabetes patients. Int J Impot Res 2003; 15: 314-317

40 Shiri R, Koskimäki J, Häkkinen J et al. Cardiovascular drug use and the incidence of erectile dysfunction. Int J Impot Res 2006; 19: 208-212

41 Javaroni $V$, Neves $M F$. Erectile dysfunction and hypertension: impact on cardiovascular risk and treatment. Int J Hypertens 2012, Article ID 627278, 11 pages doi:10.1155/2012/627278

42 Gupta S, Salimpour P, Saenz de Tejada I et al. A possible mechanism for alteration of human erectile function by digoxin: inhibition of corpus cavernosum sodium/potassium adenosine triphosphatase activity. J Urol 1998; 159: 1529-1536

43 Kley HK, Muller A, Peerenboom $\mathrm{H}$ et al. Digoxin does not alter plasma steroid levels in health men. Clin Pharmacol Ther 1982; 32: 12-17

44 Kley HK, Abendroth H, Hehrmann $R$ et al. No effect of digitalis on sex and adrenal hormones in healthy subjects and in patients with congestive heart failure. Klin Wochenschr 1984; 62: 65-73

45 Tanner $L A$, Bosco LA. Gynecomastia associated with calcium cannel blocker therapy. Arch Intern Med 1988; 148, 2: 379-380

46 Zarren HS, Black PM. Unilateral gynecomastia and impotence during low-dose spironolactone administration in men. Mil Med 1975; 140: 417-419

47 Handler J. Managing erectile dysfunction in hypertensive patients. J Clin Hypertens 2011; 13: 450-453

48 Silvestri A, Galetta P, Cerquetani E et al. Report of erectile dysfunction after therapy with beta-blockers is related to patient knowledge of side effects and is reversed by placebo. Eur Heart J 2003; 24: 19281932

49 Bansal S. Sexual dysfunction in hypertensive men. a critical review of the literature. Hypertension 1988; 12: 1-10

50 Viigimaa $M$, Doumas $M$, Vlachopoulos $C$ et al. Hypertension and sexual dysfunction: time to act. J Hyperten 2011; 29: 403-407

51 Viigimaa $M$, Lazaridis A, Doumas $M$. Management of sexual dysfunction in hypertensive patients. Cardiol Clin Prac 2012; 53-60

52 Hackett G, Kell P, Ralph D et al. British Society for Sexual Medicine guidelines on the management of erectile dysfunction. J Sex Med 2008; 5: 1841-1865

53 Hackett $G$. Hypertensive medication and erectile dysfunction. Cardiovas Therap 2010; 28: 5-7

54 Karavitakis M, Komninos C, Theodorakis PN et al. Evaluation of sexual function in hypertensive men receiving treatment: a review of current guidelines recommendation. J Sex Med 2011; 8: 2405-2414

55 Nicolai MP, Both S, Liem SS et al. Discussing sexual function in the cardiology practice. Clin Res Cardiol 2013; 102: 329-336

56 Nicolai MPJ, Liem SS, Both S et al. What do cardiologists know about the effects of cardiovascular agents on sexual function? A survey among Dutch cardiologists. Part I. Neth Heart J 2013; 21: 540-544

57 Rastogi S, Rodriguez JJ, Kapur $V$ et al. Why do patients with heart failure suffer from erectile dysfunction? A critical review and suggestions on how to approach this problem. Int J Impot Res 2005; 17 (Suppl 1): S25-S36

58 Papatsoris AG, Korantzopoulos PG. Hypertension, antihypertensive therapy, and erectile dysfunction. Angiology 2006; 57: 47-52

59 Llisterri Caro JL, Sánchez Sánchez F, Brotons Muntó F. Disfunción sessuale en la hipertensión arteriosa. Hipertensión 03/2005; 22: doi:10.1016/S0212-8241 71543-71547

60 Mas M. Hipertensión arterial, medicación antihipertensiva y disfunción eréctil: una perspectiva basada en la evidencia. Rev Int Androl 2005; 3: 13-30

61 Simonsen $U$. Interactions between drugs for erectile dysfunction and drugs for cardiovascular disease. International J Impot Res 2002; 14: 178-188

62 Ker JA. Hypertension and sexual dysfunction. S Afr Fam Pract 2012; 54: $117-118$

63 Medical Research Council Working Party on Mild to Moderate Hypertension. Adverse reactions to bendrofluazide and propranolol for the treatment of mild hypertension. Report of Medical Research Council Working Party on Mild to Moderate Hypertension. Lancet 1981; 2, 8246: 539-543 
64 Croog SH, Levine S, Sudilovsky A et al. Sexual symptoms in hypertensive patients. A clinical trial of antihypertensive medications. Arch Intern Med 1988; 148: 788-794

65 Croog SH, Levine S, Testa MA et al. The effects of antihypertensive therapy on the quality of life. N Engl J Med 1986; 314: 1657-1664

66 Hogan MJ, Wallin JD, Baer RM. Antihypertensive therapy and male sexual dysfunction. Psychosomatics 1980; 21: 234-237

67 Moss HB, Procci WR. Sexual dysfunction associated with oral antihypertensive medication: a critical survey of the literature. Gen Hosp Psychiatry 1982; 4: 121-129

68 Duncan L, Bateman DN. Sexual function in women. Do antihypertensive drugs have an impact? Drug Saf 1993; 8: 225-234

69 Hodge RH, Harward MP, West MS et al. Sexual function of women taking antihypertensive agents. J Gen Intern Med 1991; 6: 290-294

70 Grimm RH Jr, Ga Grandits, Prineas RJ et al. Long-term effects on sexual function of five antihypertensive drugs and nutritional hygienic treatment in hypertensive men and women. Treatment of Mild Hypertension Study (TOMHS). Hypertension 1997; 29: 8-14

71 Brixius $K$, Middeke $M$, Lichtenthal A et al. Nitrix oxide, erectile dysfunction and beta-blocker treatment (MR NOED study): benefit of nebivolol versus metoprolol in hypertensive men. Clin Exp Pharmacol Physiol 2007; 34: 327-331

72 Franzen $D$, Metha $A$, Seifert $N$ et al. Effects of beta blockers on sexual performance in men with coronary heart disease. A prospective, randomized and double blinded study. Int J Impot Res 2001; 13: 348-351

73 Pérez-Stable EJ, Halliday R, Gardiner PS et al. The effects of propranolol on cognitive function and quality of life: a randomized trial among patients with diastolic hypertension. Am J Med 2000; 108, 5: 359365

74 Boydak B, Nalbantgil S, Fici F et al. A randomised comparison of the effects of nebivolol and atenolol with and without chlorthalidone on the sexual function of hyperthensive men. Clin Drug Invest 2005; 25 : 409

75 Fogari $R$, Preti $P$, Derosa $G$ et al. Effect of antihypertensive treatment with valsartan or atenolol on sexual activity and plasma testosterone in hypertensive men. Eur J Clin Pharmacol 2002; 58: 177-180

76 Fogari $R$, Zoppi A, Corradi $L$ et al. Sexual function in hypertensive males treated with lisinopril or atenolol: a cross-over study. Am J Hypertens 1998; 11: 1244-1247

77 Suzuki H, Tominaga T, Kumagai $H$ et al. Effects of first-line antihypertensive agents on sexual function and sex hormones. J Hypertens 1988; 6: S649-S651

78 Wassertheil-Smoller S, Blaufox MD, Oberman A et al. Effect of antihypertensives on sexual function and quality of life: the TAIM Study. Ann Intern Med 1991; 114: 613-620

79 Fogari R, Preti P, Zoppi A et al. Effect of valsartan and atenolol on sexual behavior in hypertensive postmenopausal women. Am J Hypertens 2004; 17: 77-81

80 Doumas $M$, Tsakiris A, Douma S et al. Beneficial effects of switching from beta-blockers to nebivolol on the erectile function of hypertensive patients. Asian J Androl 2006; 8: 177-182

81 Cordero A, Bertomeu-Martínez V, Mazón P et al. Erectile dysfunction in high-risk hypertensive patients treated with beta-blockade agents. Cardiovasc Ther 2010; 28: 15-22

82 Cheng JW. Nebivolol: a third-generation beta-blocker for hypertension. Clin Ther 2009; 31: 447-462

83 Van Bortel LM, Bulpitt CJ, Fici F. Quality of life and antihypertensive effect with nebivolol and losartan. Am J Hypertens 2005; 18: 10601066

84 Prisant LM, Weir MR, Frishman WH et al. Self reported sexual dysfunction in men and women treated with bisoprolol, hydrochlorothiazide, enalapril, amlodipine, placebo, or bisoprolol/hydrochlorothiazide. J Clin Hypertens 1999; 1: 22-26

85 Riley AJ, Riley EJ. The effect of labetalol and propanolol on the pressor response to sexual arousal in women. Br J Clin Pharmacol 1981; 12: 341-344

86 Fogari R, Zoppi A, Poletti L et al. Sexual activity in hypertensive men treated with valsartan or carvedilol: a crossover study. Am J Hypertens $2001 ; 14: 27-31$

87 Chang SW, Fine R, Siegel $D$ et al. The impact of diuretic therapy on reported sexual function. Arch Intern Med 1991; 151: 2402-2408
88 Kroner BA, Mulligan T, Briggs GC. Effect of frequently prescribed cardiovascular medications on sexual function: a pilot study. Ann Pharmacother 1993; 27: 1329-1332

89 Williams GH, Croog SH, Levine S et al. Impact of antihypertensive therapy on the quality of life: effect of hydrochlorothiazide. J Hypertens 1987; 5: 29-35

90 Ogihara T, Kuramoto $K$. Effect of long-term treatment with antihypertensive drugs on quality of life of elderly patients with hypertension: a double-blind comparative study between a calcium antagonist and a diuretic. NICS-EH Study Group. National Intervention Cooperative Study in Elderly Hypertensives. Hypertens Res 2000; 23: 33-37

91 Stessman J, Ben-Ishai D. Chlortalidone-induced impotence. Br Med J 1980; 281: 714

92 Epstein $M$, Calhoun DA. Aldosterone blockers (mineralocorticoid receptor antagonism) and potassium-sparing diuretics. J Clin Hypertens $2011 ; 13:$ 644-648

93 Greenblatt DJ, Koch-Weser J. Gynecomastia and ED: complication of spironolactone. JAMA 1973; 223: 82-85

94 Pitt B, Zannad F, Remme WJ et al. The effect of spironolactone on morbidity and mortality in patients with severe heart failure. Randomized Aldactone Evaluation Study Investigators. N Engl J Med 1999; 341: 709-717

95 Pitt B, Remme WJ, Zannad F et al. Eplerenone, a selective aldosterone blocker, in patients with left ventricular dysfunction after myocardial infarction. N Engl J Med 2003; 348: 1309-1321

96 Bellmann 0, Ochs HR, Knuchel M et al. Evaluation of the hypothalamicpituitary effects of digoxin. J Clin Pharmacol 1984; 24: 474-479

97 Neri A, Aygen $M$, Zukerman $Z$ et al. Subjective assessment of sexual dysfunction of patients on long-term administration of digoxin. Arch Sex Behav 1980; 9: 343-347

98 Neri A, Zukerman Z, Aygen $M$ et al. The effect of long-term administration of digoxin on plasma androgens and sexual dysfunction. J Sex Marital Ther 1987; 13: 58-63

99 McHaffie DJ, Guz A, Johnston A. Impotence in patient on disopyramide. Lancet 1977; 1: 859

100 Korst HA, Brandes JW, Littmann KP. Disturbances of potency and spermiogenesis due to propafenon. Dtsch Med Wochenschr 1980; 105: 1187-1189

101 Omvik P, Thaulow E, Herland $O B$ et al. Double-blind, parallel, comparative study on quality of life during treatment with amlodipine or enalapril in mild or moderate hypertensive patients: a multicentre study. J Hypertens 1993; 11: 103-113

102 Bohm M, Baumhakel M, Teo K et al. Erectile dysfunction predicts cardiovascular events in high-risk patients receiving telmisartan, ramipril, or both: The ONgoing Telmisartan Alone and in combination with Ramipril Global Endpoint Trial/Telmisartan Randomized AssessmeNt Study in ACE iNtolerant subjects with cardiovascular Disease (ONTARGET/TRANSCEND) Trials. Circulation 2010; 121: 1439-1446

103 Chen Y, Cui S, Lin H et al. Losartan improves erectile dysfunction in diabetic patients: a clinical trial. Int J Impot Res 2012; 24: 217-220

104 Della Chiesa A, Pfiffner D, Meier B et al. Sexual activity in hypertensive men. J Hum Hypertens 2003; 17: 515-521

105 Düsing $R$. Effect of the angiotensin II antagonist valsartan on sexual function in hypertensive men. Blood Press Suppl 2003; 2: 29-34

106 Baumhakel M, Schlimmer N, Bohm M. Effect of irbesartan on erectile function in patients with hypertension and metabolic syndrome. Int J Impot Res 2008; 20: 493-500

107 Segal RL, Bivalacqua TJ, Burnett AL. Irbesartan promotes erection recovery after nerve-sparing radical retropubic prostatectomy: a retrospective long-term analysis. BJU Int 2012; 110: 1782-1786

108 Yang $L, Y u J, M a R$ et al. The effect of combined antihypertensive treatment (felodipine with either irbesartan or metoprolol) on erectile function: a randomized controlled trial. Cardiology 2013; 125 : 235-241

109 Dombrowski RC, Romeo JH, Aron DC. Verapamil-induced hyperprolactinaemia complicated by a pituitary incidentaloma. Ann Pharmacother 1995; 29: 999-1001 